\title{
EDITORIAL
}

\section{Competitive Advantage in Liner Shipping: A Review and Research Agenda}

\author{
PHOTIS M PANAYIDES ${ }^{1}$ \& KEVIN CULLINANE ${ }^{1}$ \\ ${ }^{1}$ Department of Shipping \& Transport Logistics, the Hong Kong \\ Polytechnic University, Hung Hom, Kowloon, Hong Kong. \\ E-mail:stlpp@polyu.edu.hk
}

\begin{abstract}
Liner shipping is a rather unique and idiosyncratic sector of the shipping industry. As such, it has attracted much attention from both researchers and policy makers. The purpose of this special issue of the International Journal of Maritime Economics is to investigate current thought in liner shipping economics and strategy. The papers included address what are and have been the major concerns of practitioners and academics, viz. market structure and regulation as well as vessel deployment and integration strategies. In an effort to induce research in another important direction, the aim of this paper is to address the issue of competitive advantage by considering the main themes that appear in the literature, viz. vertical integration and logistics strategy, strategic alliances, mergers and acquisitions, cost reduction, networks, economies of scale, regulation, pricing and shipper relationships. In so doing, this Editorial emphasises the importance of the firm as the unit of analysis and concludes by drawing attention to the need for the empirical investigation of the strategyperformance relationship.

International Journal of Maritime Economics (2002) 4, 189-209.

doi:10.1057/palgrave.ijme.9100045
\end{abstract}

Keywords: Liner shipping; competitive advantage. 
190

\section{INTRODUCTION}

What determines competitive advantage in liner shipping? What are the inherent and acquired advantages of an individual liner shipping company that enable it to outperform competitors? What strategies lead to success in acquiring or utilising such advantages? Are such advantages asset- or technology-based or, alternatively, do they accrue primarily from a firm's ability to manage effectively? How do liner shipping companies create or benefit from such advantages - is it through any or all of cost reduction, innovation in services, economies of scale, asset complementarity through joining a strategic alliance, rising barriers to market entry, government regulation or the absence or inappropriateness thereof?

Although these questions are fundamental to the economic well-being of liner shipping companies and to research in liner shipping economics and strategy, no clear answer can be given. What is clear, however, is that certain liner shipping companies (not necessarily of the same size nor resource base) outperform others on a consistent basis to achieve competitiveness, relative financial prosperity and growth. In so doing, these comparatively successful liner companies may well have decided to pursue different strategies and put in place a variety of economic and operational measures in their efforts to differentiate themselves from, and outperform, competitors.

The purpose of this special issue of the journal is to provide an insight into contemporary issues in liner shipping economics and strategy. An implicit theme that seemed to run through all the submissions received in response to the 'call for papers' and one that is obviously directly relevant to liner shipping in practice is that of competitive advantage. In setting the scene for the contents of this special issue, therefore, the aim of this paper is to survey contemporary trends in liner shipping economics and strategy in order to identify the factors that may help lead to, or predict the existence of, competitive advantage for players within the industry. In so doing, reference will be made to the theoretical concepts that may actually explain or underpin competitive advantage, as well as to the practical and research implications that the analysis reveals. The spur for such an analysis is the ever-changing nature of the dynamic liner shipping industry; a feature that is selfevident in the papers presented within this special issue and in the exemplars that are explicitly referred to within this paper.

\section{THEORIES OF COMPETITIVE ADVANTAGE}

A review of the strategic management literature reveals a number of theoretical concepts that may be applied to liner shipping in an effort to understand and explain competitive advantage within the industry. 


\section{Porter's competitive strategy framework}

Porter (1980) developed a typology of three generic strategies for creating a defensible position and outperforming competitors in a given industry. The first, overall cost leadership, emphasises low cost relative to competitors. The second strategy, differentiation, requires that the firm create something that is unique in the industry, thus permitting the firm to command higher than average prices. The third is a focus strategy, in which a firm concentrates on a particular group of customers, geographic markets, or product line segments. These three generic strategies represent three broad types of strategic groups and thus the choice of strategy 'can be viewed as the choice of which strategic group to compete in' (Porter, 1980, p. 149). Firms oriented towards specific strategies should outperform other firms in the industry.

In Porter's framework, firm performance is a function of industry and firm effects (ie market positioning) (Grant, 1991; Porter, 1991). Industry structure and firm activities are interrelated and affect each other. In addition, industry structure affects the sustainability of firm performance, whereas positioning reflects the firm's ability to establish competitive advantage over its rivals. Having gained such an attractive position, a firm can exercise market power (Teece, 1984) and thus gain 'monopoly-type' rents. These rents stem from the firm's ability to defend itself against competitive forces ('defensive' effects), or to influence them in its favour ('offensive' effects) (Porter, 1980, 1985 and 1991).

In addition, Porter views firms as capable of classification into homogeneous segments that adopt similar strategies but which are different from those of other homogeneous firm groupings. This view is comparable to that of the strategic orientation framework due to Miles and Snow (1978). They considered that organisations enact their environments and become dominated by the adaptive decision patterns they employ. They operationalised their theory by classifying firms by 'adaptive decision patterns' into four archetypes ranging from the 'prospector', through 'analysers' and 'defenders' to the least adaptive category the 'reactors'. 'Prospectors' continuously seek to locate and exploit new product and market opportunities while 'defenders' attempt to seal off a portion of the total market to create a stable set of products and customers. 'Analysers' occupy an intermediate position between the two extremes by combining the strengths of both the 'prospector' and the 'defender' so as to cautiously follow 'prospectors' into new product-market domains while at the same time protecting a stable set of products and customers. A fourth type, the 'reactor' does not have a consistent response to the entrepreneurial problem. As Lu and Marlow (1999) and Hawkins and Gray (1999) found in the contexts of Taiwanese and Asia-Pacific shipowners respectively, there is evidence to suggest that liner shipping firms may also be classified into homogeneous groups in accordance with their strategic orientation. 
192

\section{The resource-based theory}

Porter's contentions of positioning only explain part of the differences in performance within an industry. According to the resource-based view (see Conner, 1991; Grant, 1991; Mahoney and Pandian, 1992), a superior performer possesses not only an attractive position, but also unique and hard to imitate resources (Dierickx and Cool, 1989; Wernerfelt, 1984).

The resource-based view of the firm focuses on the relationships between the internal characteristics of a firm and its performance. Proponents of this view propose two alternative assumptions. First, that firms may be heterogeneous in relation to the resources and capabilities on which they base their strategies. Secondly, that these resources and capabilities may not be perfectly mobile across firms, resulting in heterogeneity among industry participants. The resource-based view has re-established the importance of the individual firm, as opposed to the industry (or particular strategic groups), as the critical unit of analysis.

Strategy selection is based on careful evaluation of available resources (strengths and weaknesses). Over time, firms continue to follow particular strategies because of both the opportunities imposed by the market environment and the constraints that result from their own accumulated asset base, organisational structure, ownership and other specific factors (Barney, 1991; McGee and Thomas, 1986). Current or future strategic decisions are constrained by past resource deployments and result in the further reinforcement of the company's prevailing strategic profile. Competitive strategy thus becomes the art of nurturing, accumulating and deploying rent-yielding resources, rather than a focus solely on erecting entry barriers or deceiving one's product-market competitors (Foss, 1996).

The main difference between Porter's contention and the resource-based view is that Porter views strategy as being primarily industry driven, whereas the resource-based perspective posits that the essence of strategy is, or should be, defined by the firm's unique resources and capabilities.

\section{VERTICAL INTEGRATION AND LOGISTICS STRATEGY}

A major contemporary trend in liner shipping strategy is vertical integration and diversification into inland transport, terminal operation and logistics. In this special issue, Trevor Heaver considers such developments in detail by addressing the evolving roles of shipping lines within the context of international logistics.

The operational integration of sea and inland transport was initiated by the need for greater efficiency and effectiveness and became feasible as the result of containerisation and other technological developments linked to intermodal capability. Hence, economies of scale in containership operations, the rationalisa- 
tion of mainline ports of call, the resulting need to access an ever larger cargo base (or hinterland) and the increased capability of inland transport systems to carry large volumes of cargo over a long distance (and within a sufficiently short time frame) have been instrumental in this. Archambault (1989) notes that because of the inherent intermodal character of container operations, the structural interdependence between the two transportation activities (ie sea and land) is inevitable and the synchronisation of mainline containership schedules with those of interlining modes has come to be an efficient way to create further economies of scale.

In recent years there has been ample evidence to suggest a significant interest of ocean carriers in inland transportation and the provision of a total door-to-door logistics package to their clients. The reasons for such an interest vary and may include, among others, trends in rationalisation and liberalisation taking place in liner shipping, intense competition for market share, depressed freight rates and additional customer requirements. Frankel (1999, p. 10) states, for instance: 'The time when shippers used an array of freight forwarders, truckers, clearance agents, shipping companies, railway services, etc and various financial, freight insurance and other institutions are gone. Today major customers demand and get onewindow integrated just-in-time and efficient all-inclusive door-to-door service at a predetermined price. This is what the market demands now.' Semejin and Vellenga (1995) succinctly document the benefits that may accrue to ocean carriers adopting such a strategic move.

The advent of supply chain management has also contributed to the changing nature of the way transportation organisations conduct their business. Carriers have been transformed from product dispensers and distributors to become a critical element in supply chain service performance, hence expanding the scope of their operations. Contemporary carriers need to play a crucial role in supply chain integration and the dissemination of information (Wagner and Frankel, 2000). Carriers themselves, industry observers and researchers are paying more attention, therefore, to the value and position of carriers within established networks (Coyne and Dye, 1998).

The potential advantages of a vertically integrated intermodal transport structure have been recognised since the early 1980s and are embodied within the considerable investments, primarily by ocean carriers, that have made in the different modes and service capabilities along a supply chain. Potential benefits to carriers include increased business and market share; survival in the competitive international environment (Archambault, 1989); the facilitation of management and co-ordination (Hayuth, 1987); economies of scale and scope that can lead to lower cost structures and higher profits (Mahoney, 1985); shared creativity along all stages of the logistical process (Bowersox, 1988; Gardner and Cooper, 1988); capitalising on the relative advantages of the 
194

various transport modes (Hayuth, 1987); and greater routeing flexibility (Mahoney, 1985). In addition, benefits have also been identified for shippers. Such benefits include improvement in service quality; ease in transacting business dealings; simplified claims settlement, filing, tracing of shipment and paperwork needed for shipment; and increased control over shipment (see Semejin and Vellenga, 1995; Vellenga et al., 1999).

The benefits have also been recognised by many mega-carriers, where integration of shipping and logistics businesses has resulted in the provision of a door-to-door service through carrier-owned or -directed connecting modes and inhouse logistics functions and services. Heaver reviews such developments and considers the organisational strategies of lines in relation to terminal management, intermodal services and logistics services. A more detailed consideration of the economics of vertical integration and control is provided by Panayides (2001a and 2002).

Heaver notes that '... lines are likely to differ in the way they interpret market developments and in their assessment of the best strategies to capitalise on the opportunities.' Evidence of this is given by the different strategies of liner companies in providing logistics and value-added services. It is evident that companies do not follow the same strategies in entering the logistics markets or providing value added services, yet performance and competitiveness may not be solely determined by, or dependent upon, the adoption of such strategies. Beyond recognition of the status quo in strategic orientation, the challenge is, of course, for scientific research to determine in what way and why companies differ and what strategies are adopted in order to capitalise on available market opportunities. In addition, how does a particular strategy relate to the performance of the company? Past research has not addressed this issue and empirical investigation is much needed. In addition, any conceptual work that will have the potential to drive empirical assessment should be firmly grounded in established theoretical principles of both economics and strategic management.

The anecdotal evidence suggests that liner shipping companies may be classified in accordance with the Miles and Snow typology, as not all companies exhibit the same strategic orientation and the latter may resemble a particular Miles and Snow category. An empirical classification will assist in explaining why certain companies are able to outperform others, since the Miles and Snow typology is related to performance (Zahra and Pearce, 1990).

For instance, the strategic orientation of CP Ships closely resembles the characteristics of the 'prospector' type of company, as it is seemingly continuously seeking new growth opportunities, as evidenced through a coherent strategy of acquisitions and new market development. CP Ships showed improved financial results in 2000 and 2001, which can be taken as an indicator 
of performance. The basic premise of the typology is that the 'defender', 'analyser' and 'prospector' strategies, if properly implemented, can lead to effective performance. Each type emphasises different functions to produce a set of sustainable, distinctive competencies. The 'reactors', on the other hand, lack a coherent strategy and, therefore, the other three types of company will inevitably outperform them.

Heaver provides an excellent analysis of the strategies of liner shipping companies vis-à-vis their expanding role in the global market by way of investment in inland/intermodal transport and logistics. He states, however, that 'the success of a line. . is not dependent on its ability to offer logistics services', something which points to the presence of a differential strategy as a pre-cursor to success. To empirically assess this contention, Porter's framework, as well as the resource-based view, is immensely relevant.

The major characteristic of the liner shipping industry has been the intense competition, which has been attributed to politically and technologically induced excess capacity coupled with low marginal costs (Agman, 1976; Marx, 1953) and the part this plays in influencing conditions of entry (Davies, 1986). Strategic investment in ports and terminals, as well as in logistics management, affects the conditions of entry and contributes to growth, competitiveness and profitability. The ability of a firm to offer logistics services by embarking on a vertical integration strategy through investment in either ports or terminals and diverse inland transport may serve as a barrier to entry for new firms and create a position of defensible competitive advantage. A firm will be able to offer total logistics services as demanded by customers, with its service automatically differentiated from that of competitors.

Empirical work is required, however, to identify if vertical integration into inland transport and expansion into logistics is profitable in liner shipping. What is the relationship between such a strategy and any ultimate measure of performance, and to what extent will this be translated into sustainable competitive advantage? In this case, the theoretical contentions of the resourcebased view of competitive advantage may also offer a platform to drive further research in the area.

\section{STRATEGIC ALLIANCES, MERGERS AND ACQUISITIONS (M\&A)}

The formation and membership of strategic alliances has been a prominent feature in the liner shipping industry in the 1990s. This has prompted the scientific examination of the strategic alliance concept (eg Evangelista and Morvillo, 1999 and 2000; Midoro and Pitto, 2000; Panayides and Song, 2001; Song and Panayides, 2002; Ryoo and Thanopoulou, 1999). 
196

The objectives of modern liner shipping companies include risk and investment sharing, the reaping of economies of scale, cost-control and a capability to increase service frequencies. Against a background of the globalisation of world markets and poor profitability and financial performance, these objectives have prompted the formation of strategic alliances. It can be claimed that the formation of, or even defection from, strategic alliances as well as the implementation of other strategies (such as M\&A) are all driven by the need to accomplish corporate objectives. Hence, various writers (eg Fossey, 1994; Gardiner, 1997; Midoro and Pitto, 2000) have credited the formation of global strategic alliances in shipping to achieving various objectives which may be classified as follows:

- Financial objectives: profit maximisation, increase in shareholder wealth, capital investment sharing and financial risk reduction;

- Economic objectives: cost reduction, economies of scale;

- Strategic objectives: entry in new markets, wider geographical scope, increase in purchasing power;

- Marketing objectives: satisfy customer requirements better, eg higher frequency, flexibility, reliability, network expansion (ie offering a greater variety of routes and destinations); and

- Operational objectives: increase in frequency of services, vessel planning and coordination on a global scale.

Despite the fact that there have been obvious advantages in the formation of strategic alliances, it might be claimed that in certain circumstances those advantages have not been achieved in practice. In consequence, some liner shipping companies have experienced instability and changes in strategic direction. Hence, companies have given great consideration in recent years to whether alliance or acquisition would be the most effective avenue for achieving organisational objectives and growth (eg Alix et al., 1999). The reasons for the instability characterising liner shipping strategic alliances may be traced back to the behaviour of the member companies in the alliance. Such behaviour may arise from the need to achieve individual organisational objectives that may have an impact on the co-operation of the partners. In addition, other factors such as the number of partners in an alliance, the nature of their role and contribution to the alliance, the level of mutual trust and the complexity of the task itself may play a significant role in alliance instability (eg Killing, 1988). Midoro and Pitto (2000) provide a conceptual examination of the above factors and found them to be valid in a liner shipping context. In addition, they point to the existence of intra-alliance competition as another key force driving alliance instability. Hence, an in-depth study of the co-operative behaviour of alliance partners would be of great practical relevance and importance. 
Midoro and Pitto (2000) suggest that alliance stability and efficiency may be achieved by focusing on one or more of the following three measures:

- $\quad$ reduction in the number of partners;

- differentiation in their roles and contributions; and

- co-ordination of sales and marketing activities.

The problems associated with strategic alliances and their consequent relative instability prompted a strategic shift in recent years towards closer integration between companies in the form of mergers and acquisitions. The reasons for closer integration in the form of $M \& A$ as well as their consequences have been given some attention by various authors (Meersman et al., 1999; Panayides and Gong, 2001 and 2002).

An important reason for a merger is the achievement of cost-reduction through operating synergies and economies of scale. For instance, it was stated that about three-quarters of the US\$130 million savings resulting from the NOLAPL deal have stemmed from the combined company's more efficient usage of APL's sea terminals and container freight trains, as well as the ships owned by both the individual companies. Another potential advantage is the achievement of market or monopoly power. Heaver et al. (2000, pp. $368-369$ ) state that the greater market share of lines realised through mergers ... may create some initial heightened market power, but this is unlikely to result in sustained high profit margins in the dynamically competitive international shipping and logistics industry.' This proposition provides a useful basis for empirical investigation as to its merits or otherwise, since market power is one of the reasons cited in the general literature as an antecedent to M\&As (eg Kim and Singal, 1993; Panayides, 2001b).

A number of theories and models have been proposed to account for the emergence of strategic alliances as well as their operation. They include the transaction cost approach (Hennart, 1998; Williamson, 1985), game theory (Parkhe, 1993), the strategic behaviour model (Das and Teng, 1996, 1997, 1998 and 1999; Tyler and Steensma, 1998), social exchange theory (Axelrod, 1984; Blau, 1964), power-dependence theory (Chisholm, 1989; Pfeffer and Salancik, 1978) and the resource-based view (Das and Teng, 2000).

In general, however, empirical research into liner shipping strategic alliances has been limited and, as a result, current understanding is not empirically grounded. This is surprising bearing in mind the importance of strategic alliances in liner shipping and the dynamism and consequent instability that characterises them. There is obvious value in borrowing concepts from the general literature and conceptually drawing parallels and conclusions in the liner shipping industry using (primarily) anecdotal evidence. However, such results are not conclusive 
198

and can, at best, be used as a guideline to further empirical work that should address specific research questions. To what extent does a merger, an acquisition or joining a strategic alliance contribute to the objectives of a company and to a competitive advantage? What contributes to instability in strategic alliances? What is the outcome of the alliance membership-performance relationship?

One of the objectives of liner shipping companies that may be achieved through a merger or acquisition is the maximisation of shareholder wealth. Panayides and Gong (2001 and 2002) empirically examined the wealth creation effects of a merger or acquisition as evidenced by the change in stock price performance of liner shipping companies upon the announcement of the planned event. It was found that the announcement of a merger or acquisition has a significant impact on the stock price of the acquired company in particular.

In this special issue, Bergantino and Veenstra apply the network theory to the study of global strategic alliances in liner shipping. Through their analytical framework it is argued that exploitation of network externalities is the main scope of shipping network integration also determining their optimal size. However, it is network co-ordination costs that may cause problems of instability leading to frequent restructuring that limits the potential of achieving interconnectivity advantages, particularly cost-savings.

Co-operation and instability have been the major characteristics of strategic alliances in liner shipping. The empirical examination of the behaviour of liner companies within strategic alliances may be achieved through the application of game theory (Panayides and Song, 2001; Song et al., 2001; Song and Panayides, 2002). In this respect, the theory of the core (Telser, 1978 and 1982) has been used to support the assertion that liner shipping cannot support stable systems for long and that 'a core-based model effectively explains the incidence of collusion and competition in ocean shipping markets' (Pirrong, 1992, p. 129).

\section{COST REDUCTION, NETWORKS AND ECONOMIES OF SCALE}

Fundamental questions in the economics of liner shipping involve cost reduction, the establishment of route networks and the achievement of economies of scale. These economic issues relate to the proposition by Porter (1980) that absolute cost advantage, differentiation and specialisation are generic strategies that may be pursued for the achievement of a competitive advantage.

Cost reduction and achievement of economies of scale have been the subject of past research. The issue of ship size, route deployment and economies of scale has been addressed by McLellan (1997), Cullinane and Khanna (1999), Cullinane and Khanna (2000), Lim (1994 and 1998) and Gilman (1999). Cullinane and Khanna (1999) found that the economics of container ship operation are crucially 
dependent on port productivity and that, taking into account the extant model input parameters (particularly those relating to costs and productivity levels at the time the analysis was conducted), an optimum ship size of 8,000 TEU was derived for the Europe - Asia trade. In addition that there are no diseconomies of scale in port for ship sizes of less than 1,500 TEU. Cullinane et al. (1999) asserted that economies of scale are present on particular routes for particular ship sizes and that continued improvements in port productivity would serve to increase even further ship size optima for all routes.

The issue of cost advantage is addressed in this special issue by Baird (2002) who considers the concepts of direct multi-port calls and hub and spoke service schedules vis-à-vis their relative cost effectiveness. A cost analysis is conducted based on a weekly Europe - Asia - USEC pendulum service in ships ranging from 4,000 TEU to 6,000 TEU. The results suggest that a move towards hub and spoke operations in Northern Europe, with the radical suggestion of Orkney as an offshore hub, would yield cost savings to carriers of about $7 \%$. This amounts to a total saving in direct costs of about $\$ 8.6$ million per annum. It is further suggested that with this configuration the same level of service can be maintained with one less ship, thus leading to an indirect saving in capital and charter costs. In total, the combined savings are predicted to amount to approximately $\$ 20$ million per annum. As the author points out, based on the results from this analysis, the strength of the economic argument for the implementation of hub and spoke operations utilising a single transhipment point in Northern Europe (possibly Orkney) would appear to be irrefutable. If this is the case, then the competitiveness of the traditional port cities of Northern Europe will be undermined, especially since they are typically located in sensitive and shallow estuaries and in the midst of major population centres where traffic congestion at sea and on land is becoming increasingly unsustainable.

The establishment of route networks can assist companies in offering specialised services to particular geographical regions. Gilman (1999) discusses the strategy of operating multiple services with a degree of specialisation in itineraries. Companies in multi-route alliances can exploit opportunities for specialisation in itineraries and combine very broad overall distribution, and high service, quality with a tight control on the number of vessels in each string, thus culminating in operating cost advantages. Robinson (1998) makes the case for new hierarchically organised port/shipping networks. These networks are broadly classified into high order networks where efficiency and cost are paramount and lower order networks that will include a mix of hub and direct-port calls that will focus on different market segments. The relationship between networks, efficiency, cost and specialisation is once again evident as strategies adopted by lines.

It is clear that companies embark on strategies of cost-cutting and efficiency improvement measures. The question that arises is to what extent such strategies 
200

lead to improvement in performance and competitive advantage. The anecdotal evidence would appear to be mixed.

A company that has shown improved performance during 2000 and 2001 is P\&O Nedlloyd. Evidence for this improved performance is provided by the financial accounts of the company. For the year 2000 the company recorded an operating profit of US $\$ 201$ million, up from US $\$ 7$ million the year before, producing a return on sales of $4.9 \%$. Net profit before tax increased from a loss of US $\$ 51$ million to a profit of US\$140 million. In much tougher market conditions, this has been followed up by an operating profit of US\$77 million during the first six months of 2001, an increase of $157 \%$ compared to the same period in 2000 . This yielded a return on sales of $3.7 \%$. Profit before tax increased from a loss of US \$1 million to a profit of US\$50 million. Although there is no empirical evidence to indicate the reasons for the improved performance, certain facts relating to Porter's competitive strategy may account for it. As postulated by Porter, industry and firm effects may account for improved performance.

In the case of P\&O Nedlloyd the market has clearly been in its favour, as witnessed by the $8 \%$ increase in its liftings during 2000. In addition, the company adopted a number of strategies comparable to Porter's views. These include the introduction of several new and modified services (differentiation), the introduction of a radical cost-cutting programme (cost advantage) and the acquisition of smaller lines and investment in a tremendous newbuilding programme to take advantage of economies of scale (Beddow, 2001).

Unlike P\&O Nedlloyd, the Singapore-based NOL fared very poorly financially in 2001. Its disappointing financial results were attributed to market conditions brought about by the Asian financial crisis, the acquisition of APL in 1997 and the acquisition of GATX Logistics in 2001 for US\$210 million. However, similar market conditions were also faced by the Hong Kong-based OOCL that posted significant growth in 2001 and an all-round sound financial performance despite the weak global economic conditions. The chief executive of OOCL attributed the robust financial performance to a cost-cutting strategy and investment in new and more efficient vessels. Ignoring the potential impact of any significant intervening variables, it would seem clear that companies may outperform others on the basis purely of the competitive strategies that they pursue. Mixed results were also reported by other major mega-carriers. For the first six months of 2001, P\&O reported an overall reduction in operating profit. Taipei-based Evergreen Marine Corporation reported significantly reduced profits for the first six months of 2001 . On the other hand, the A. P. Moller Group has reported impressive results for the same period.

The Taiwan-based ocean carrier Yang Ming provides an interesting example of cost-reduction and focus. The company does not deviate by a great margin from its core service, which is focused on the intra-Asian trades. The company's 
strategy has been cost-reduction through rationalisation and service improvements. This has been achieved by developing close co-operation with other companies operating in the same trades and forging a consortium with K-Line and Cosco in order to enjoy synergies and rationalisation through slot exchange agreements and better utilisation of capacity. Although primarily a regionallyfocused company, Yang Ming is the thirteenth largest ocean carrier in terms of TEU carried in 2001. In line with past strategy, the company is looking to exploit market niche opportunities and to forge ties with companies as a means of risk minimisation (Dekker, 2001).

An article in the August 2001 issue of Lloyd's Shipping Economist noted that the enthusiasm for cost advantages through co-operation has waned as the limitations have become apparent. It further states that 'while on-going costcutting is essential to compete, it is essentially a no-win situation-all are following the same path, and the limbo pole is shifted ever downwards as the cost savings and productivity gains are passed on to customers in lower freight rates.' Lim (1998) suggests that the strategy of having a low-cost position in order to achieve a competitive advantage is misleading in the context of the liner shipping industry. He goes on to suggest that, rather than low-cost positions and potential price wars, co-operation should be pursued in liner shipping for the achievement of a competitive advantage. It is evident, however, that despite its merits and benefits, co-operation itself does not seem to be a sustainable strategy for all companies. So what is really at the core of instability problems in liner shipping? Although there is no empirical evidence to support this, Porter's views may be insufficient in the quest for understanding and explaining competitive advantage in liner shipping. On the other hand, a new perspective (see Penrose, 1959) that may be utilised in future research and is firmly grounded in institutional economic thought (as opposed to neo-classical economics) is the resource-based view of the firm.

The resource-based view represents a new concept now at the forefront of strategic management research and its conceptual and empirical application in liner shipping can make a significant contribution to the understanding of firm performance and competitive advantage. The importance of the resource-based view in the context of competitive and economic analysis in liner shipping is the increased emphasis on the firm, rather than the industry as the unit of analysis. Research in liner shipping economics has concentrated on the industry and markets as a means for understanding and explaining economic performance (eg Jansson and Shneerson, 1987) and to some extent the concept of the theory of the firm has been ignored. In fact, Haralambides and Veenstra (2000) note that the attention of researchers in past years has concentrated on two types of models, viz. the optimisation of liner shipping operations and market structure. The advent of novel scientific thought suggests that it is about time for a new approach 
to be given conceptual and empirical attention; one which revolves around the modelling of the firm modelled at a micro-analytic level.

\section{REGULATION, PRICING AND SHIPPER RELATIONSHIPS}

A significant influence on the competitiveness of liner shipping companies is the issue of regulation and the resulting implications, particularly with respect to the setting of price and the relationship with the major shipper-clients.

Important lessons about liner shipping regulation and its implications for the antitrust debate and competitiveness can be deduced from the excellent analysis of the North American regulatory regime that is provided by Mary Brooks. A central theme that arises is the ever-important antitrust immunity afforded to liner conferences and the implications that might arise as the result of the potential abolition of such immunity. The relationship between shippers, shippers' councils and liner companies has been strained over recent years particularly with respect to price setting on the part of the liners and the opposition of shippers advocating unfair treatment, market power and the violation of antitrust rules. A significant piece of legislation directed at apportioning rights and responsibilities in liner shipping regulation is the US Ocean Shipping reform Act (OSRA) 1998. The implications of the OSRA 1998 have been examined by Shashi Kumar (1999), Weil (1999) and Brooks (2000a). Although the OSRA retains conference antitrust immunity, it has had an impact on conference formation and the carrier-shipper relationship, particularly with respect to the price/service relationship.

Price setting has been a contentious issue in liner shipping. Its importance and topicality is explained by the formation of liner conferences whose conduct and economic performance has perplexed economists (see Scherer, 2000) and by the antitrust implications of joint corporate behaviour on the part of liner shipping companies. Scholarly work in liner shipping economics has been preoccupied with the rather static foundations of price competition. Contestable markets theory for instance, which has been found to be relevant in a liner shipping industry context (Davies, 1986; Franck and Bunel, 1991; Graham, 1998; Shashi Kumar, 1995; Zerby, 1988) but also criticised (Jankowski, 1989; Pearson, 1987), is firmly rooted in the premise that firms act as if operating in a perfectly competitive situation with only limited, or even zero, barriers to entry. The formulation of antitrust laws has also been influenced by such analyses. Price alone, however, cannot be taken to be solely responsible for competitive advantage and the enhancement of wealth. Developments in the productive efficiency of firms and the quality of their services, as well as their growth, and the ease with which they can enter or exit, can be critical. The markets of the industrialised economies have been increasingly characterised by innovation and growth (Audretsch, 1995), 
something which may not be compatible with a reliance on price competition for the formulation of antitrust legislation. This issue presents major challenges in the regulation of liner shipping and in research aiming to explore the determinants of competitive advantage. For instance, it may be suggested that ownership advantages accrue as the result of a regulatory regime that affords protection to liner companies at the expense of the shipper-consumer. On the other hand, and as Scherer (2000) noted, it is possible that not all shippers have been equally vociferous in their opposition to cartels in shipping that are also characterised as 'imperfect cartels' in their conduct and performance, something that may have sustained their continuous viability.

In terms of regulation and legislation in liner shipping, it seems that competition laws and antitrust legislation are the most important issues. Research implications emanate from the evolution of industrial economic thought from a static to a dynamic basis whereby competition is recognised as sometimes destructive and that firm capability plays a major role in determining market performance. As a result, the efficacy of competition laws that use price as a major determinant of competitiveness may be brought into question.

The performance of liner shipping companies and in particular the perception of the clients with respect to a service provider's ability to meet promises is fundamental for client attraction, retention and competitiveness. Shippers, customers, consignees and other stakeholders are spending more time qualifying carriers who must conform to more stringent criteria related to service performance and evaluation (Brooks, 1999 and 2000b). As such the concept has received attention in the literature with notable contributions by Brooks (1990, 1998, 1999, 2000b), Durvasula et al. (2000), Kent and Parker (1999), Lu and Marlow (1997) and Lu (2000). A number of approaches have been utilised in these empirical investigations and particular patterns of choice criteria for selection and evaluation have emerged. Interestingly, price has not been the most important factor in carrier selection criteria and in general, service quality in terms of punctuality was among the most critical factors. Of course, marketing strategy is pivotal to achieving competitive advantage. The modest attention it has received provides further opportunities for research. In fact, sustaining a differential advantage requires a balance of customer and competitive perspectives. One of the most important factors that will increase the chances of higher business performance is market orientation. According to Kohli and Jaworski (1990) market orientation is composed of three sets of activities, viz. (1) organisation-wide generation of market intelligence about current and future customer needs; (2) dissemination of the intelligence across departments; and (3) organisation-wide responsiveness to it.

Moreover, an expanding body of research findings points to a strong relationship between market orientation and superior performance (Day, 1990; 
Fritz, 1996). The evidence indicates that companies that are market oriented display favourable organisational performance compared with companies that are not market oriented (Narver and Slater, 1993).

\section{CONCEPTUAL AND EMPIRICAL IMPLICATIONS}

It is clear from this review that certain liner shipping companies are able to outperform others on the basis of the strategies that they pursue. The identification of what contributes to the achievement of a competitive advantage should be at the centre of a new body of empirical research.

Applying the concepts found in the strategic management literature, a conceptual model should take into account the strategic orientation of liner shipping companies towards achieving a competitive advantage. This conceptual model should address not only the factors that influence the selection of strategy and the actual strategies deployed, but also the environmental factors which mould what strategies are adopted and how they are applied.

Future research may utilise classificatory as well as explanatory approaches. A possible conceptualisation may aim at the development of taxonomies of companies according to their strategic orientation, competitive advantage strategies and organisational performance. Taking market conditions as constant for all firms, the organisational characteristics and past resource deployments of firms will determine their strategic orientation and the strategies pursued for the achievement of a competitive advantage. The aim is to identify the company's competitive strategic orientation, the strategies pursued for the achievement of a competitive advantage and to link these to performance and organisational characteristics. The use of structural equation models may be useful in this case. The fundamental aim and importance of such an analysis is the identification of the constructs that lead to and/or explain the competitive advantage enjoyed (or that may be enjoyed) by individual companies involved in the liner shipping industry.

The concepts discussed in the strategy literature have been empirically examined and applied in various industries. A number of studies discusses the measures used for operationalising strategic orientation (Conant et al., 1990; James and Hatten, 1995; Shortell and Zajac, 1990), Porter's competitive strategy (Dess and Davis, 1984; Miller and Friesen, 1986; White, 1986) and the resourcebased view (Azzone et al., 1995). The measurement of strategic orientation may be accomplished using the self-typing paragraph approach that is commonly used in strategic management research (eg James and Hatten, 1995).

Performance measurement is a multidimensional construct (eg Chakravarthy, 1986; Kaplan and Norton, 1996; Walker and Ruekert, 1987) that is influenced by both the level of analysis (eg functional vs business strategy) and strategy type (eg 
'prospector' vs 'defender'). A number of measures have been utilised in the measurement of business performance. Two commonly used measures of economic performance are 'return on assets' and 'growth in sales'. 'After tax return on total assets' is commonly viewed as one operational measure of the efficiency of a firm with regard to the profitable use of its total asset base (Ansoff, 1965; Bourgeois, 1980; Gale, 1972). Ansoff (1965, p. 42) asserts, for instance, that 'return on investment is a commonly and widely accepted yardstick for measuring business success.' 'Growth in sales' provides a second measure of economic performance that reflects 'how well an organisation relates to their environment' (Hofer and Schendel, 1978, p. 4) by successfully expanding their product-market scope (Ansoff, 1965). In measuring business performance it is important to acknowledge the limitations of various measures. As stated by Chakravarthy (1986), no single measure of profitability is capable of discriminating excellence. Performance needs to be assessed in relation to maximising shareholder wealth as well as the ability of the company to transform itself in relation to changes in the environment.

\section{CONCLUSION}

In this era of globalisation and fierce competition, where strategic decisions may lead to the growth or demise of a company, the strategy-performance relationship is of the utmost importance in liner shipping.

In the context of achieving and sustaining a competitive advantage, empirical research in liner shipping has been quite limited. As opposed to the operational study of route design and/or ship deployment and the physical movement of cargoes or market structure studies, the evolution of research in maritime economics points to the importance of research that is applied to shipping companies as corporate entities which have as their objectives increased competitiveness, growth and profitability. The implicit assumption of this paper is that operational measures relate to some generic strategies for the achievement of a competitive advantage and the efficacy of those strategies needs to be evaluated. The case is also made for adopting a micro-analytic approach in modelling issues in maritime economics and strategy in conjunction with the already widely-applied aggregate market structure approach. Although it is not the intention to enter into a debate as to the merits, or otherwise, of the neoclassical vis-à-vis the institutional approach in economic methodology (this is done elsewhere-see Blaug, 1997), suffice it to say that the contention of the authors is that the micro-analytic, firm-specific approach has the potential for making a significant contribution to liner shipping economics and strategy. It is towards this direction that more empirical work needs to be undertaken. 
206

\section{REFERENCES}

Agman, R. 1976: Competition, rationalization and the United States shipping policy. Journal of Maritime Law and Commerce 8: 1-58.

Alix, Y, Slack, B and Comtois, C. 1999: Alliance or acquisition? Strategies for growth in the container shipping industry: the case of CP Ships. Journal of Transport Geography 7: 203-208.

Ansoff, HI. 1965: Corporate strategy. McGraw-Hill: New York.

Archambault, M. 1989: Intermodalism and liner shipping intermodal approaches. Transportation Practitioners Journal 56: 151-163.

Audretsch, DB. 1995: Innovation and Industry Evolution. The MIT Press: Cambridge, MA.

Azzone, G, Bertele, U and Rangone, A. 1995: Measuring resources for supporting resource-based competition. Management Decision 33: 57-62.

Axelrod, R. 1984: The Evolution of Co-operation. Basic Books: New York.

Barney, J. 1991: Firm resources and sustained competitive advantage. Journal of Management 17: 99-120.

Beddow, M. 2001: PONL's initiatives paying off. Containerisation International (December): 36-37.

Blau, PM. 1964: Exchange and Power in Social Life. Wiley: New York.

Blaug, M. 1997: The Methodology of Economics. 2nd ed., Cambridge University Press: Cambridge.

Bourgeois, L. 1980: Performance and consensus. Strategic Management Journal 1: 227-248.

Bowersox, DJ. 1988: Logistical partnerships. In: Partnerships: A Natural Evolution in Logistics. The Ohio State University: Columbus, OH. pp. 1-13

Brooks, MR. 1990: Ocean carrier selection criteria in a new environment. Logistics and Transportation Review 26: 339-355.

Brooks, MR. 1998: Performance evaluation in the North American transport industry: users' views. Transport Reviews 18: 1-16.

Brooks, MR. 1999: Performance evaluation of carriers by North American logistics firms. Transport Reviews 19: $273-284$

Brooks, MR. 2000a: Sea Change in Liner Shipping: Regulation and Managerial Decision-Making in a Global Industry. Pergamon: Amsterdam.

Brooks, MR. 2000b: Performance evaluation of carriers by North American companies. Transport Reviews 20: 205-218.

Chakravarthy, BS. 1986: Measuring strategic performance. Strategic Management Journal 7: 437-458.

Chisholm, D. 1989: Co-ordination without Hierarchy: Informal Structures in Multi-organisational Systems. University of California Press: Berkeley, CA.

Conant, JS, Mokwa, MP and Varadarajan, PR. 1990: Strategic types, distinctive marketing competencies and organisational performance: A multiple measures-based study. Strategic Management Journal 11: 365383.

Conner, KR. 1991: A historical comparison of resource-based theory and five schools of thought within industrial organisation economics: Do we have a new theory of the firm? Journal of Management 17: 124154.

Coyne, KP and Dye, R. 1998: The competitive dynamics of network-based businesses. Harvard Business Review 76: 99-109.

Cullinane, K and Khanna, M. 1999: Economies of scale in large container ships. Journal of Transport Economics and Policy 33: 185-208.

Cullinane, KPB and Khanna, M. 2000: Economies of scale in large containerships: optimal size and geographical implications. Journal of Transport Geography 8: 181 - 195.

Cullinane, K, Khanna, M and Song, D-W. 1999: How big is beautiful: Economies of scale and the optimal size of containership. Proceedings of the International Association of Maritime Economists, Liner Shipping: What's Next? Centre for International Business Studies: Halifax. pp. 108-140.

Davies, J. 1986: Competition, contestability and the liner shipping industry. Journal of Transport Economics and Policy 20: 299-312. 
Das, TK and Teng B. 1996: Risk types and inter-firm alliance structures. Journal of Management Studies 33: 827-843.

Das, TK and Teng, B. 1997: Sustaining strategic alliances: options and guidelines. Journal of General Management 22: 69-88.

Das, TK and Teng, B. 1998: Resource and risk management in the strategic alliance making process. Journal of Management 24: 21-42.

Das, TK and Teng, B. 1999: Managing risks in strategic alliances. Academy of Management Executive 13: 50-62.

Das, TK and Teng, B. 2000: A resource-based theory of strategic alliances. Journal of Management 26: 31-61.

Day, GS. 1990: Market-Driven Strategy: Processes for Creating Value. The Free Press: New York.

Dekker, N. 2001: Flying high. Containerisation International (September): 48-51.

Dess, GG and Davies, PS. 1984: Porter's generic strategies as determinants of strategic group membership and organisational performance. Academy of Management Journal 27: 467-488.

Dierickx, I and Cool, K. 1989: Asset stock accumulation and sustainability of competitive advantage. Management Science 35: 1504-1511.

Durvasula, S, Lysonski, S and Mehta, SC. 2000: Business-to-business marketing. Service recovery and customer satisfaction issues with ocean shipping lines. European Journal of Marketing 4: 433-452.

Evangelista P and Morvillo A. 1999: Alliances in liner shipping: an instrument to gain operational efficiency or supply chain integration? International Journal of Logistics: Research and Applications 2: 21-38.

Evangelista P and Morvillo A. 2000: Cooperative strategies in international and Italian liner shipping. International Journal of Maritime Economics 2: 1-16.

Foss, N. 1996: Strategy, economics and Michael Porter. Journal of Management Studies 33: 1-24.

Fossey, J. 1994: Birth of the global alliance. Containerisation International (October) 49-55.

Franck, B and Bunel, JC. 1991: Contestability, competition and regulation. The case of liner shipping. International Journal of Industrial Organisation 9: 141-159.

Frankel, E. 1999: Intermodal integration. Lloyd's Shipping Economist 21: 10-11.

Fritz, W. 1996: Market orientation and corporate success: findings from Germany. European Journal of Marketing 30: 59-74.

Gale, B. 1972: Market share and rate of return. The Review of Economics and Statistics ???: 412-423.

Gardiner, P. 1997: The Liner Market. Lloyd's of London Press: London.

Gardner, J and Cooper, MC. 1988: Elements of strategic partnerships. In: Partnerships: A Natural Evolution in Logistics. The Ohio State University: Columbus, OH. pp. 15-31.

Gilman, S. 1999: The size economies and network efficiency of large containerships. International Journal of Maritime Economics 1: 39-59.

Graham, MG. 1998: Stability and competition in intermodal container shipping: finding a balance. Maritime Policy and Management 25: 129-147.

Grant, RM. 1991: The resource-based theory of competitive advantage: implications for strategy formulation. California Management Review 33: 114-135.

Haralambides, HE and Veenstra, AW. 2000: Modelling performance in liner shipping. In Hensher, DA and Button, KJ (eds). Handbook of Transport Modelling, chapter 40. Elsevier Science: Oxford. pp. 643-656.

Hawkins, JE and Gray, R. 1999: Making choices for Asia-pacific shipping. International Journal of Maritime Economics 1: 57-71.

Hayuth, Y. 1987: Intermodality: Concept and Practice. Lloyd's of London Press: London.

Heaver, T, Meersman, H, Moglia, V and Van de Voorde, E. 2000: Do mergers and alliances influence European shipping and port competition? Maritime Policy and Management 27: 363-373.

Hennart, JF. 1988: A transaction cost theory of equity joint ventures. Strategic Management Journal 9: 361374.

Hofer, C and Schendel, D. 1978: Strategy Formulation: Analytical Concepts. West Publishing: St. Paul.

James, WL and Hatten, KJ. 1995: Further evidence on the validity of the self-typing paragraph approach: Miles and Snow strategic archetypes in banking. Strategic Management Journal 16: 161-168.

Jankowski, WB. 1989: Competition, contestability and the liner shipping industry: a comment. Journal of Transport Economics and Policy 23: 199-203. 
208

Jansson, JO and Shneerson, D. 1987: Liner Shipping Economics. Chapman and Hall: London.

Kaplan, R and Norton, D. 1996: The Balanced Scorecard: Translating Strategy into Action. Harvard Business School Press: Boston, MA.

Kent, JL and Parker, RS. 1999: International containership carrier selection criteria: shippers/carriers differences. International Journal of Physical Distribution and Logistics Management 29: 398-408.

Killing, JP. 1988: Understanding alliances: the role of task and organisational complexity. In: Contractor, FG and Lorange, G (eds). Co-operative Strategies in International Business. Lexington Books: New York. pp. 169-185.

Kim, EH and Singal, V. 1993: Mergers and market power: evidence from the airline industry. American Economic Review 83: 549-569.

Kohli, AK and Jaworski, BJ. 1990: Market orientation: the construct, research propositions and managerial implications. Journal of Marketing 54: 1-18.

Lim, S-M. 1994: Economies of ship size: A new evaluation. Maritime Policy and Management 21: 149-166.

Lim, S-M. 1998: Economies of scale in container shipping. Maritime Policy and Management 25: 361-373.

Lu, CS. 2000: Logistics services in Taiwanese maritime firms. Transportation Research Part E 36: 79-96.

Lu, CS and Marlow, P. 1997: Liner Shipping Service Attributes: A Review. Occasional Paper, Department of Maritime Studies and International transport, University of Wales: Cardiff.

Lu, CS and Marlow P. 1999: Strategic groups in Taiwanese liner shipping. Maritime Policy and Management 26: $1-26$.

Mahoney, JH. 1985: Intermodal Freight Transportation. Eno Foundation for Transportation: Westport.

Mahoney, JT and Pandian, JR. 1992: The resource-based view within the conversation of strategic management. Strategic Management Journal 13: 363-380.

Marx, D. 1953: International Shipping Cartels. Princeton: Princeton University Press.

McGee, J and Thomas, H. 1986: Strategic groups: theory, research, and taxonomy. Strategic Management Journal 7: 141-160.

McLellan, RG. 1997: How big is too big? Maritime Policy and Management 24: 193-211.

Meersman, H, Moglia, F and Van de Voorde, E. 1999: Mergers and alliances in liner shipping: what do European port authorities have to fear? Proceedings of the IAME 1999 Conference, Liner Shipping: What's Next? Centre for International Business Studies, Dalhousie University, Halifax. pp. 204-220.

Midoro, R and Pitto, A. 2000: A critical evaluation of strategic alliances in liner shipping. Maritime Policy and Management 27: 31-40.

Miles, RE and Snow, CC. 1978: Organisational Strategy, Structure and Process. McGraw-Hill: New York.

Miller, D and Friesen, PH. 1986: Porter's (1980) generic strategies and performance: an empirical examination with American data. Part II: performance implications. Organisation Studies 7: 255-261.

Narver JC and Slater SF. 1993: The effects of market orientation on business profitability. Journal of Marketing 54: 20-35.

Panayides, PhM. 2001a: The economics of organisation in intermodal transport: a transaction cost approach. Proceedings of the 9th WCTR Conference. July 22-27, Seoul, Korea.

Panayides, PhM. 2001b: Antecedents and consequences of mergers and acquisitions in liner shipping. Proceedings of the 9th WCTR Conference. July 22-27, Seoul, Korea.

Panayides, PhM. 2002: The economic organization of intermodal transport. Transport Reviews 22: (in press).

Panayides, PhM and Gong, XH. 2001: Corporate strategy and stock price reaction in the liner shipping industry: an event study approach. Proceedings of the 9th WCTR Conference. July 22-27, Seoul, Korea.

Panayides, PhM and Gong, XH. 2002: The stock market reaction to merger and acquisition announcements in liner shipping. International Journal of Maritime Economics 4: 55-80.

Panayides. PhM and Song, DW. 2001: Liner shipping strategic alliances as co-operative games: A conceptual framework. Proceedings of the International Association of Maritime Economists (IAME) Conference. The Hong Kong Polytechnic University, Hong Kong.

Parkhe, A. 1993: Strategic alliance structuring: A game theory and transaction cost examination of inter-firm cooperation. Academy of Management Journal 36: 794-829. 
Pearson, R. 1987: Some doubts on the contestability of liner shipping markets. Maritime Policy and Management 14: 71-78.

Penrose, E. 1959: The Theory of The Growth of The Firm. John Wiley \& Sons: New York.

Pfeffer, J and Salancik, GR. 1978: The External Control of Organisations: A Resource Dependence Perspective. Harper and Row: New York.

Pirrong, SG. 1992: An application of core theory to the analysis of ocean shipping markets. The Journal of Law and Economics 35: 89-131.

Porter, M. 1980: Competitive Strategy. The Free Press: New York.

Porter, M. 1985: Competitive Advantage. The Free Press: New York.

Porter, M. 1991: Toward a dynamic theory of strategy. Strategic Management Journal 12: 95-117.

Robinson, R. 1998: Asian hub/feeder nets: the dynamics of restructuring. Maritime Policy and Management 25: 21-40.

Ryoo, D-K and Thanopoulou, H. 1999: Liner alliances in the globalisation era: a strategic tool for Asian container carriers. Maritime Policy and Management 26: 349-367.

Scherer, FM. 2000: On maritime shipping conferences. In Scherer, FM (ed). Competition Policy, Domestic and International, chapter 11. Edward Elgar: UK. pp. 161-177.

Semejin, J and Vellenga, DB. 1995: International logistics and one-stop shopping. International Journal of Physical Distribution \& Logistics Management 25: 26-44.

Shashi Kumar, N. 1995: Competition and models of market structure in liner shipping. Transport Reviews 15: $3-26$.

Shashi Kumar, N. 1999: The US OSRA of 1998: An analysis of its economic impact on carriers, shippers and third parties. Proceedings of the IAME 1999 Halifax Conference. Centre for International Business Studies, Dalhousie University, Halifax, Canada. pp. 7-29.

Shortell, SM and Zajac, EJ. 1990: Perceptual and archival measures of Miles and Snow's strategic types: A comprehensive assessment of reliability and validity. Academy of Management Journal 33: 817-832.

Song, DW, Panayides, PhM and Wang, TF. 2001: Inter-organisational relations in liner shipping as a cooperative game. Eastern Asia Society for Transportation Studies 3: 247-262.

Song, DW and Panayides, PhM. 2002: A conceptual application of co-operative game theory in liner shipping strategic alliances. Maritime Policy and Management 3: (in press).

Teece, D. 1984: The Competitive Challenge. Bollinger: Boston, MA.

Telser, LG. 1978: Economic Theory and the Core. University of Chicago Press: Chicago.

Telser, LG. 1982: A Theory of Efficient Cooperation and Competition. Cambridge University Press: Cambridge.

Tyler BB and Steensma, HK. 1998: The effects of executives' experiences and perceptions on their assessment of potential technological alliances. Strategic Management Journal 19: 939-965.

Vellenga, DB, Semejin, J and Vellenga, DR. 1999: One-stop shopping for logistics services: a review of the evidence and implications for multi-modal companies. Journal of Transportation Management 3: 31-58.

Walker, O and Ruekert, R. 1987: Marketing's role in the implementation of business strategies: a critical review and conceptual framework. Journal of Marketing 51: 15-33.

Wagner, WB and Frankel, R. 2000: Quality carriers: critical link in supply chain relationship development. International Journal of Logistics: Research and Applications 3: 245-257.

Wernerfelt, B. 1984: A resource-based view of the firm. Strategic Management Journal 5: 171-180.

White, R. 1986: Generic business strategies, organisational context, and performance: an empirical investigation. Strategic Management Journal 7: 217-231.

Weil, RT. 1999: OSRA 1998: A step forward or away from an international consensus in the regulation of ocean liner shipping. Proceedings of the IAME 1999 Halifax Conference. Centre for International Business Studies, Dalhousie University, Halifax, Canada. pp. 30-57.

Williamson, OE. 1985: The Economic Institutions of Capitalism. The Free Press: New York.

Zahra, SA and Pearce, JA. 1990: Research evidence on the Miles-Snow typology. Journal of Management 16: 751-768.

Zerby, JA. 1988: Clarifying some issues relating to contestability in liner shipping, and perhaps eliminating some doubts. Maritime Policy and Management 15: 5-14. 